Article

\title{
Hydrophilic Submicron Nanogel Particles for Specific Recombinant Proteins Extraction and Purification
}

\author{
Gaëlle Levourch ${ }^{1}$, Noureddine Lebaz ${ }^{2}$ (i) and Abdelhamid Elaissari ${ }^{2, *}$ \\ 1 Unité mixte CNRS-BioMérieux, Ecole Normale Supérieure de Lyon, 46 Allée d'Italie, 69364 Lyon, France; \\ happy.phd2020@gmail.com \\ 2 Univ Lyon, University Claude Bernard Lyon 1, CNRS, LAGEPP, UMR 5007, 43 Boulevard du \\ 11 Novembre 1918, F-69100 Villeurbann , France; noureddine.lebaz@univ-lyon1.fr \\ * Correspondence: abdelhamid.elaissari@univ-lyon1.fr
}

Received: 6 June 2020; Accepted: 23 June 2020; Published: 24 June 2020

check for updates

\begin{abstract}
In biomedical diagnosis and bionanotechnologies, the extraction and purification of proteins and protein derivatives are of great interest. In fact, to purify recombinant proteins for instance, new methodologies and well appropriate material supports need to be established and also to be evaluated. In this work, hydrophilic nanohydrogel particles were prepared for recombinant proteins extraction for purification purpose. The prepared nanohydrogel polymer-based particles are hydrophilic below the volume phase transition temperature (TVPT) and dehydrated above the TVPT, due to the thermally sensitive poly( $\mathrm{N}$-alkyl acrylamide) and poly( $\mathrm{N}$-alkyl methacrylamide) derivatives. Then, the use of heavy metal ions in the presence of such functional particles should specifically capture recombinant proteins (i.e., proteins bearing a poly(histidine) part). In order to understand and to optimize the specific capture and the purification of recombinant proteins, various parameters have been investigated as a systematic study. Firstly, the adsorption was investigated as a function of $\mathrm{pH}$ and protein concentration. According to high hydration of the prepared nanohydrogel, no marked adsorption was observed. Secondly, the effect of $\mathrm{pH}$ was investigated and found to be the driven parameter affecting the metal ions immobilization and the recombinant proteins complexation. As a result, high protein complexation was observed at basic $\mathrm{pH}$ compared to non-complexation at acidic $\mathrm{pH}$ medium. The immobilized proteins via complexation were released by changing the $\mathrm{pH}$. This decomplexation seems to be effective but depends on fixation conditions and particle surface structure.
\end{abstract}

Keywords: nanohydrogel particles; adsorption; complexation; metal ions; recombinant protein

\section{Introduction}

Polymer latexes have received increasing interest as supports in numerous applications, especially in the biomedical field, due to the versatility of many heterophase polymerization processes (emulsion, dispersion, microemulsion, precipitation, etc.) for making well-defined microspheres of a specific size range and surface group functionalities [1-4].

Nowadays, to enhance the sensitivity in biomedical diagnostics, the purification and the concentration steps are essential. In fact, in various biomedical domains, the limiting step is mainly related to the needed purification of a small amount of biological sample. This step has to be rapid, low cost, and easy to set down. In the case of proteins or proteic materials, this is generally performed using chromatography [5]. Unfortunately, such a method has a few drawbacks: the protein solution obtained after purification is highly diluted and the cost and the implementation are too restricting. Consequently, the challenge is to develop new tools and methodologies leading to a rapid and specific proteins purification and the alternative 
could be the use of colloidal latex particles [6]. The use of latex is generally due to the high specific surface (several $\mathrm{m}^{2}$ per gram of particles), and their modular physicochemical properties [7].

In recent years, stimuli-responsive nanoparticles have been largely studied in the literature because of their specific properties that make them interesting candidates for a multitude of applications, especially in the biomedical field [8]. These smart materials exhibit structural and conformational changes as a consequence of their environment properties' fluctuations (temperature, $\mathrm{pH}$, ionic strength, etc.) [9-11]. For instance, the hydrophilic latexes are employed as solid-phase supports for the immobilization of biomolecules such as proteins or peptides in view of reducing non-specific proteins adsorption $[12,13]$.

Specific attention has been paid to the investigation of poly-N-isopropylacrylamide (polyNIPAM) as thermally-sensitive polymer since the late 1980s [14]. This polymer exhibits a low critical solubility temperature (LCST) in the range of $30-35{ }^{\circ} \mathrm{C}$ in aqueous solution [15]. It collapses above the LCST and swells below it [16]. PolyNIPAM-based aqueous microgels were first synthesized by a surfactant-free emulsion polymerization of aqueous NIPAM and methylene-bis-acrylamide [17]. This simple method gives uniform submicron particles. To confer to the fabricated colloidal microgel particles $\mathrm{pH}$ additional sensitivity, microcapsules with interpenetrating polymer network structure based on polyNIPAM and poly(acrylic acid) are synthetized and characterized [18-20]. Moreover, core-shell gels consisting of water-insoluble core latex particles coated with a polyNIPAM shell are reported. Duracher et al. (1998) prepared and characterized monodisperse cationic polystyrene-polyNIPAM core-shell particles [21,22]. They used aminoethyl methacrylate hydrochloride (AEM) as a comonomer and methylene-bis-acrylamide as crosslinker and emphasized that the structure of the hydrophilic shell layer depends upon the polymerization process and amount of AEM used. Thermosensitive polyNIPAM coated nanomagnetic particles $\left(\mathrm{Fe}_{3} \mathrm{O}_{4}\right)$ are also investigated and reviewed by $\mathrm{Yi}$ et al. (2013) [23]. Other inorganic core materials such as silica and metals are reported [24-26]. More recently, thermoresponsive nanoparticles with a liquid-crystalline surfactant core are prepared from the mixture of neutral block copolymer salts containing poly(ethylene oxide) and PolyNIPAM blocks as shell materials [27]. Details on the core properties that display liquid-crystalline structure may be found in [28]. Inversely, PolyNIPAM could be used as the core and coated with different organic or inorganic shells such us poly(N-isopropylmethacrylamide) [29] and silica [30].

Homogeneous and core-shell gels are tested for the sorption and desorption of proteins [31,32], enzymes [33,34], nucleic acids [35], peptides [13], and bacteria [12]. They are also used as drug carriers [36-38] and as antimicrobial encapsulating agents [39,40].

In this work, the idea was to evaluate the potential application of various functional thermally sensitive submicron polymer particles as a solid support for recombinant proteins purification. The chosen latexes are used as a model only. The use of colloidal particles needs the control of the possible interactions involved in the adsorption process, which may compete with the complexation. In fact, to purify proteins, only the complexation should be the driven parameter in the immobilization process. Consequently, both the adsorption and the immobilization via metal ions should be investigated as a systematic study and as a function of various physicochemical parameters such as $\mathrm{pH}$, metal ion concentration, protein amount, and surface particles nature.

\section{Materials and Methods}

\subsection{Materials}

The Core 119 protein is from the capsid of the hepatitis $\mathrm{C}$ virus (HCV). This recombinant protein has a histidine tag on the $\mathrm{C}$-terminus. Its theoretical isoelectric point is at $\mathrm{pH}=12.01$ and its molecular weight is $\mathrm{M}_{\mathrm{w}} \approx 14514 \mathrm{~g}$. $\mathrm{mol}^{-1}$. This recombinant protein was purified with Ni-NTA Magnetic Agarose Beads (QIAGEN, Hilden, Germany).

Disodium hydrogen phosphate and sodium phosphate buffers were from Prolabo (Paris, France) and used to prepare phosphate buffers at different $\mathrm{pH}$ values. Water (deionized and deoxygenated) 
was of Milli-Q grade (Millipore SA, France). Sodium chloride from Prolabo and nickel (II) sulfate hexahydrate from Aldrich Chemical were used as received. Coomassie Plus Protein Assay Reagent was from Pierce and was used as a reactant to quantify protein concentration.

Styrene monomer (99\% from Janssen, Beerse, Belgium) was purified by vacuum distillation and stored at $-20^{\circ} \mathrm{C}$. N-isopropylacrylamide (NIPAM) (from Eastman Kodak Company, Rochester, USA) was purified via solubilization and crystallization processes using a 60/40 hexane/toluene mixture. Methylene bisacrylamide (MBA) (from Aldrich, Darmstadt, Germany) was used as a cross-linking monomer and 2-aminoethylmethacrylate hydrochloride (AEMH) (from Kodak) was used as a functional monomer. These two reactants (MBA and AEMH) were used as received. 2,2'-azobis(2-amidinopropane) dihydrochloride (V50) (from Wako, Neuss, Germany) was used as radical cationic initiator and it was recrystallized from 50/50 acetone/water mixture and dried under vacuum before use. Potassium persulfate (KPS) (reagent grade from Prolabo) was used as radical anionic initiator without further purification. $\mathrm{N}$-(vinylbenzylimino)-diacetic acid (IDA) was prepared according to Morris et al.'s (1959) [41] reaction and purified before use.

\subsection{Methods}

\subsubsection{Preparation of Cationic and Anionic Latexes}

Polystyrene core polyNIPAM shell (CS) latex was prepared using a shot-growth polymerization process. At first, batch polymerization (in $200 \mathrm{~mL}$ water) of styrene (18 g) and NIPAM (2 g) using V50 ( $0.2 \mathrm{~g})$ as a cationic initiator was carried out. After $79 \%$ polymerization conversion, an aqueous solution containing NIPAM, MBA, AEMH, and V50 was injected into the preformed latex particles and the polymerization was then conducted overnight $[21,22]$. The detailed recipe is given in Table 1 .

Table 1. Recipe of core-shell and nanohydrogel particles preparation.

\begin{tabular}{ccccc}
\cline { 2 - 4 } Product (g) & CS & HG1 & HG2 \\
\cline { 2 - 5 } Water (mL) & 200 & 50 & 50 \\
NIPAM & $5.07^{*}$ & 1 & 1 \\
AEMH & $0.147^{* *}$ & $/$ & $/$ \\
IDA & $/$ & $/$ & 0.012 \\
MBA & $0.069^{* *}$ & 0.120 & 0.120 \\
V50 & $0.122^{* *}$ & $/$ & $/$ \\
KPS & $/$ & 0.012 & 0.012 \\
\hline
\end{tabular}

Nanohydrogel (HG1) was prepared via polymerization and was carried out in a 100-mL round-bottomed four necked flask equipped with a glass anchor shaped stirrer, condenser, and nitrogen inlet. Monomers (NIPAM and MBA) dissolved in boiled and deoxygenated water were then added. After temperature equilibrium $\left(80^{\circ} \mathrm{C}\right)$, the solution was stirred for $30 \mathrm{~min}$ at polymerization temperature before introducing the initiator (KPS) dissolved in water. The solution was stirred at a constant rate under nitrogen during polymerization and the reaction was carried out during $6 \mathrm{~h}$. The recipe is given in Table 1.

Regarding the second nanohydrogel (HG2), it was prepared following the same process as for HG1 via polymerization and was carried out in a 100-mL round-bottomed four necked flask equipped with a glass anchor shaped stirrer, condenser, and nitrogen inlet. Monomers (NIPAM, IDA, and MBA) dissolved in boiled and deoxygenated water were then added. After temperature equilibrium $\left(80^{\circ} \mathrm{C}\right)$, the solution was stirred for $30 \mathrm{~min}$ at polymerization temperature before introducing the initiator (KPS) dissolved in water. The solution was stirred at a constant rate under nitrogen during polymerization and the reaction was carried out at $80{ }^{\circ} \mathrm{C}$ during $6 \mathrm{~h}$. The recipe is given in Table 1 as well. 


\subsubsection{Characterization of Latexes}

The prepared polymer particles were cleaned by repetitive centrifugation and redispersion in deionized water in order to remove the free water-soluble polymer and the free electrolytes before any characterization.

Particle size distributions were determined by quasi-elastic light scattering (QELS, N4 from Coultronics, France). Electrophoretic mobility of highly diluted latex particles in $10^{-3} \mathrm{M} \mathrm{NaCl}$ solution was measured as a function of $\mathrm{pH}$ and temperature from 20 to $50^{\circ} \mathrm{C}$ using Zetasizer $3000 \mathrm{HS}$ (Malvern Instruments, Grovewood, UK) in order to examine the influence of both $\mathrm{pH}$ and temperature on surface charge density variation.

The shape of the particles was observed by scanning electron microscopy (SEM, Hitachi S 800 (Ueden, Germany), CMEABG at Claude Bernard University, Lyon I, France). Samples for SEM were prepared by placing a drop of the dispersion directly onto an aluminum sample holder and the latex drop was dried at room temperature. All specimens for SEM measurements were sputtered with gold at fixed conditions (time $150 \mathrm{~s}$, current $20 \mathrm{~mA}$, voltage $2 \mathrm{kV}$ ). A standard voltage $(10 \mathrm{kV})$ was used for SEM experiments.

\subsubsection{Adsorption and Complexation of Protein onto Latex Particles}

Adsorption and complexation experiments were performed in 10-mM phosphate buffers and at a given $\mathrm{pH}$ (ranging between 5 to 9). The data reported in this study are the average values of duplicate or triplicate experiments. The adsorption study was performed without adding nickel ions.

The amount of protein adsorbed was determined via depletion method by quantifying residual free proteins in the supernatant after removing polymer particles using a centrifugation step $(13,000$ $\mathrm{rpm}$ for $30 \mathrm{~min}$ at $20^{\circ} \mathrm{C}$ ). The concentration of protein molecules in the supernatant was determined using the Bradford's method [42] based on the calibration curve.

\subsubsection{Complexation as a Function of $\mathrm{pH}$}

For the complexation experiments, latex particles and $10^{-2} \mathrm{mM}$ of nickel ions were first incubated at $20{ }^{\circ} \mathrm{C}$ during $15 \mathrm{~min}$ in phosphate buffer solutions at various $\mathrm{pH}$ (5 to 9 ) to allow the complexation of nickel ions on colloidal particles first. Thereafter, proteins and particles-nickel ions were mixed and incubated at $20^{\circ} \mathrm{C}$ for $2 \mathrm{~h}$. After the incubation time, the amounts of immobilized protein were determined as described above.

\subsubsection{Complexation as a Function of Nickel and Protein Concentrations}

In order to study the influence of nickel ions concentration on the protein complexation at various $\mathrm{pH}$ and at $20^{\circ} \mathrm{C}$, different quantities of nickel (ranging from $10^{-4}$ to $10^{-1} \mathrm{mM}$ ) were added to the colloidal particles containing systems. The same procedure described above was followed for investigating the influence of protein concentration after adding various quantities of protein ranging between 7 and $35 \mathrm{mg}$ per gram of polymer particles.

\subsubsection{Decomplexation Study}

The release from the complexation was studied as a function of $\mathrm{pH}$ (fixation at neutral or basic $\mathrm{pH}$ and removal at acidic $\mathrm{pH}$ ). The experiments were performed as follows: first, protein adsorption was performed at neutral or basic $\mathrm{pH}$ (ranging from 7 to 9 ) at $20^{\circ} \mathrm{C}$. Secondly, the protein-nickel-latex particle complexes were separated from the medium and redispersed in the same volume of acidic phosphate buffer solution ( $\mathrm{pH}=5$ or 6). Release from complexation was then carried out at $20^{\circ} \mathrm{C}$ under magnetic stirring (at $900 \mathrm{rpm}$ ). Finally, the amount of released protein was determined by measuring the free protein concentration in the supernatant as described above.

Due to the complex nature of the used latexes, the amounts of protein adsorbed or complexed were expressed in $\mathrm{mg}$ of adsorbed protein per $\mathrm{g}$ of latex particles rather than in $\mathrm{mg}$ per $\mathrm{m}^{2}$. 


\section{Results and Discussion}

\subsection{Characterization of the Particles}

\subsubsection{Scanning Electron Microscopy Analysis}

Scanning Electron Microscopy (SEM) was first performed and the obtained images show that all particles are spherical and seem also to be submicronic and narrowly distributed in size (Figure 1). The real size cannot be determined from SEM images for such particles. In fact, the platteness of such soft particles induces an overestimation of the particle size as reported by Hazot et al. (2003) [43].

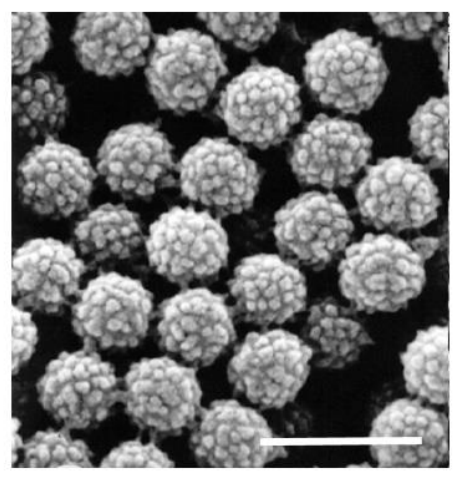

CS

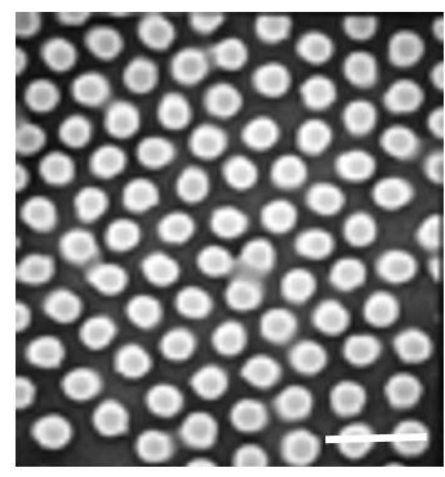

HG1

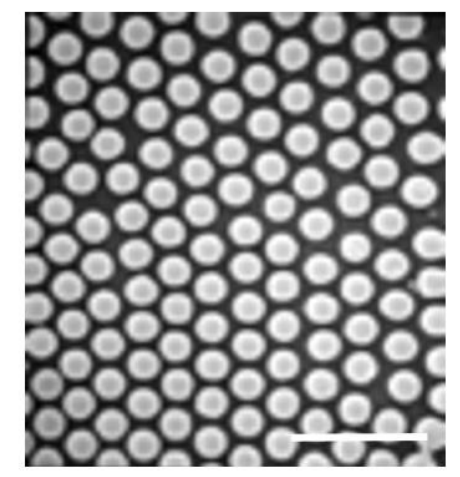

HG2

Figure 1. Scanning Electron Microscopy (SEM) analysis of the prepared particles (scale bar is $1 \mu \mathrm{m}$ ).

\subsubsection{Hydrodynamic Particle Size}

Hydrodynamic mean particle size variation as a function of temperature measured by QELS in $10^{-3}$ $\mathrm{M} \mathrm{NaCl}$ solution is reported in Figure 2 and Table 2 for all dispersions. The measured hydrodynamic mean particle size (z-average) for all latexes decreases with increasing the temperature from 15 to $70{ }^{\circ} \mathrm{C}$, reflecting changes in the shrinkage of these soft particles. For the core-shell particles (CS), the volume phase transition was found to be close to the corresponding LCST $\left(\approx 32^{\circ} \mathrm{C}\right)$ of pure polyNIPAM in a salt free medium. Regarding HG1 and HG2, the drastic changes were found to be close to $40^{\circ} \mathrm{C}$ for both of them (transition temperature of the non-crosslinked polyNIPMAM homopolymer: $44^{\circ} \mathrm{C}$ ). Similar results have already been reported by Kawaguchi and al. (1992) [44] for cross-linked polyNIPAM nanohydrogel particles and by Duracher and al. (1998) [21] for polyNIPMAM nanohydrogel particles.

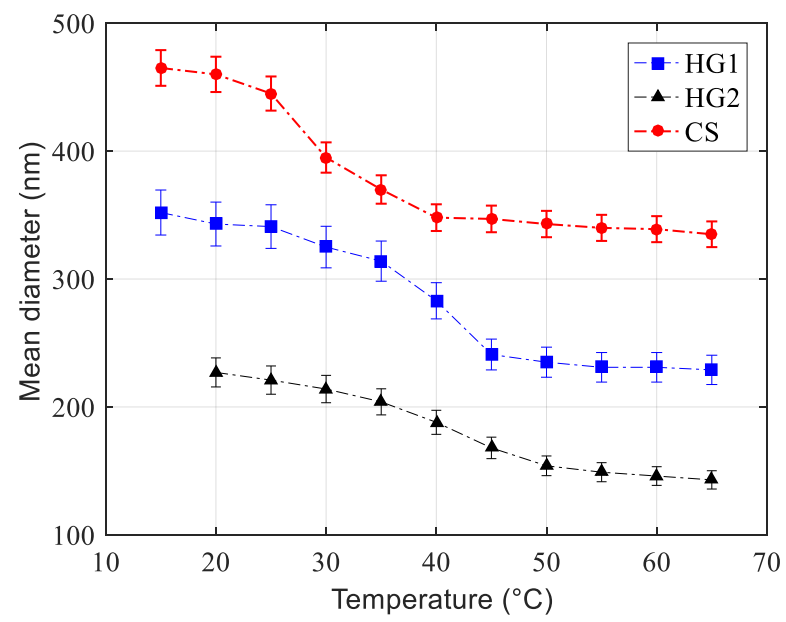

Figure 2. Hydrodynamic mean particle size of HG1, HG2, and core shell (CS) as a function of temperature in $1 \mathrm{mM} \mathrm{NaCl}$ solution. 
Table 2. Colloidal characteristics of cationic core-shell and anionic nanohydrogel latexes. Hydrodynamic mean particle size (z-average) was determined by quasi-elastic light scattering (QELS); the thermally-sensitive nanohydrogel hydrated thickness layer is calculated as $\left(\delta=\left(D_{20}{ }^{\circ} \mathrm{C}-D_{50^{\circ}} \mathrm{C}\right) / 2\right)$.

\begin{tabular}{cccc}
\hline Sample & $\left.\mathbf{D}_{\mathbf{h}}\left(\mathbf{2 0}{ }^{\circ} \mathbf{C}\right) \mathbf{( n m}\right)$ & $\left.\mathbf{D}_{\mathbf{h}} \mathbf{( 5 0}{ }^{\circ} \mathbf{C}\right)(\mathbf{n m})$ & $\delta(\mathbf{n m})$ \\
\hline CS & 460 & 343 & 58.5 \\
HG1 & 350 & 225 & 62.5 \\
HG2 & 220 & 140 & 40.0 \\
\hline
\end{tabular}

\subsubsection{Electrophoretic Mobility}

The electrophoretic mobility of all dispersions was measured as a function of $\mathrm{pH}$ in a 10-mM phosphate buffer and at $25{ }^{\circ} \mathrm{C}$, and the obtained results are reported in Figure 3. For the core-shell-like particles, the measured electrophoretic mobility exhibits a positive character in the studied $\mathrm{pH}$ domain ranging from $\mathrm{pH}=5$ to $\mathrm{pH}=9$. The positive electrophoretic mobility can be attributed to the cationic character of both V50 used as initiator and AEMH used as functional monomer. Electrophoretic mobility decreases as a function of $\mathrm{pH}$ due principally to deprotonation of both V50 and AEMH. A similar tendency has been reported by Duracher et al. (1998) [21].

For HG1 and HG2 nanohydrogels, a constant and negative electrophoretic mobility is observed in the investigated $\mathrm{pH}$ range, reflecting the negative character and low surface charge density attributed mainly to the presence of sulfate groups originating from KPS used as the initiator in the polymerization recipe. The slight difference between HG1 and HG2 can be attributed to the presence of both carboxylic and sulfate groups on HG2 nanogel particles. However, the difference is not significant regarding experimental uncertainty as reported in Figure 3.

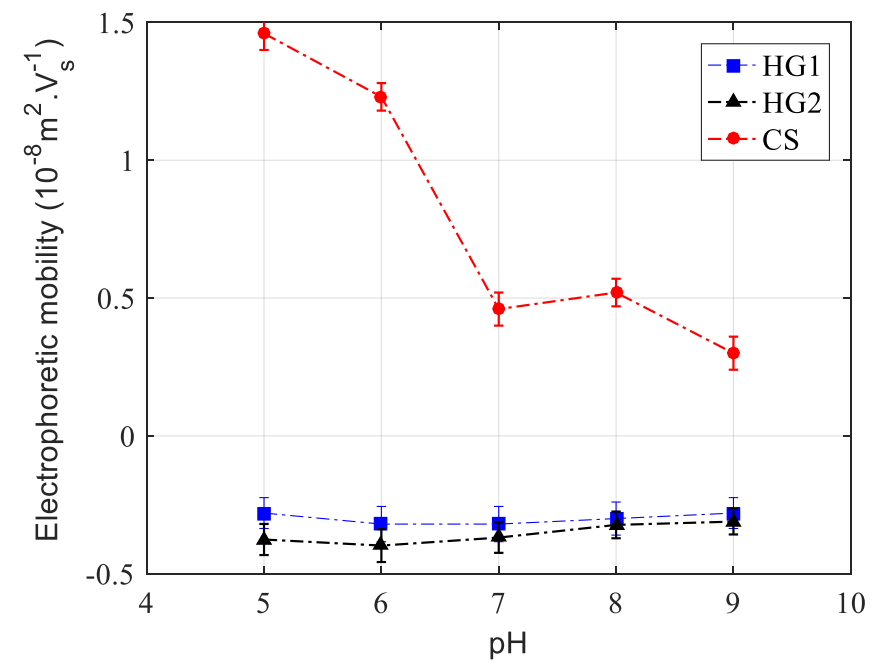

Figure 3. Electrophoretic mobility of CS, HG1, and HG2 as a function of $\mathrm{pH}$ at $25^{\circ} \mathrm{C}$ and in $10 \mathrm{mM}$ phosphate buffer.

Electrophoretic mobility was also investigated as a function of temperature. The obtained results are reported in Figure 4 for all dispersions. For the three dispersions, the measured electrophoretic mobility increases (in absolute value) with increasing temperature. This is attributed to changes in the hydrodynamic size as a function of temperature. In fact, with increasing temperature, the hydrodynamic size decreases, leading to an increase in the surface charge density and consequently to an increase in the electrophoretic mobility. Similar tendency has been already reported by Pelton and Chibante (1986) [17], Kawaguchi et al. (1992) [44], and then Nabzar et al. (1998) [45] for polyNIPAM microgel particles. 


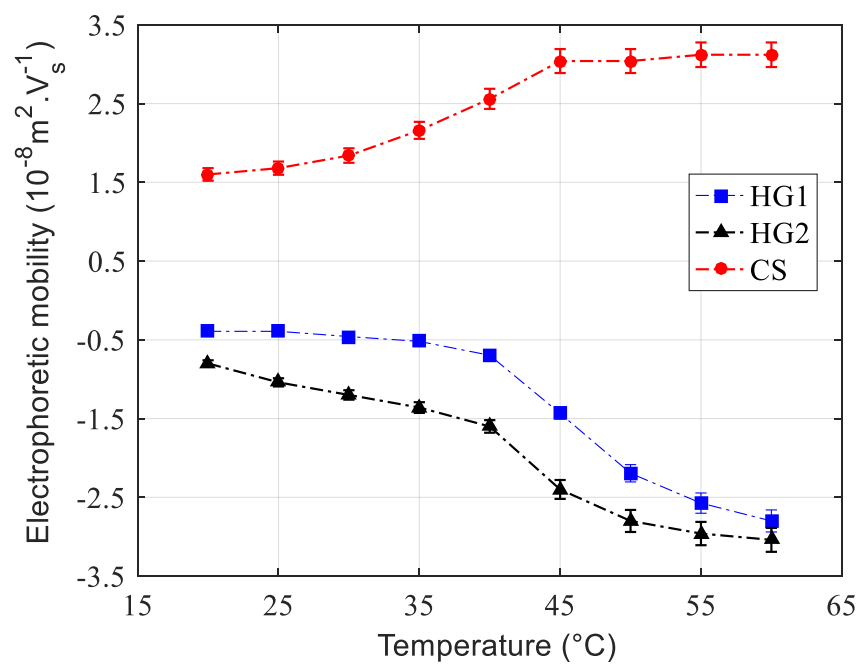

Figure 4. Electrophoretic mobility of HG1, HG2, and CS as a function of temperature at $\mathrm{pH}=7$ in a 10-mM phosphate buffer.

\subsection{Protein Immobilization}

\subsubsection{Protein Adsorption}

Protein adsorption onto all particles has been investigated as a function of $\mathrm{pH}$, in a 10-mM phosphate buffer and at $20{ }^{\circ} \mathrm{C}$. The obtained results are reported in Figure 5. As well known, proteins adsorption onto thermally sensitive $\mathrm{N}$-alkylacrylamide derivatives based particles, and on hydrated surfaces is low and even undetectable [46]. Whereas, the adsorption on dehydrated charged nanohydrogels above the volume phase transition temperature is attributed to the dehydration process which induces both hydrophobic and electrostatic interactions [47]. In the case of the present study, the adsorption results show that adsorption is high for HG2 compared to CS and HG1 irrespective of $\mathrm{pH}$. This can be attributed to the possible presence of hydrogen binding between protein and nanogel particles. For CS and HG1, the non-observed adsorption above $\mathrm{pH}=5$ can be attributed to the total absence of both hydrophobic and attractive electrostatic interactions. Whereas, the slight adsorbed amount at $\mathrm{pH}=5$ can be attributed to the possible hydrogen binding adsorption process.

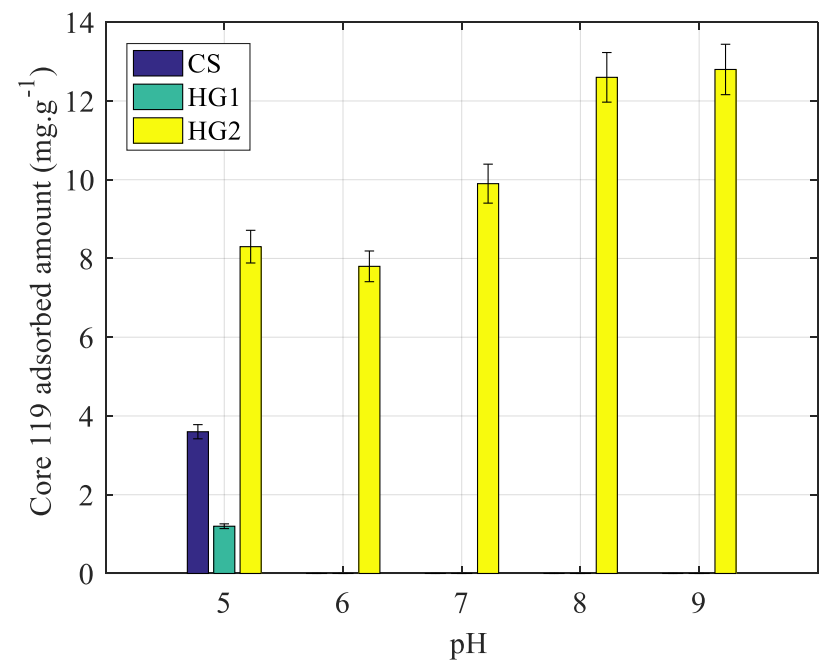

Figure 5. $\mathrm{pH}$ influence of Core 119 adsorption onto CS, HG1, and HG2 latexes. Conditions: phosphate buffer at different $\mathrm{pH}$ (from 5 to 9), ionic strength $10 \mathrm{mM}$, adsorption temperature $20^{\circ} \mathrm{C}$. 
In brief, the low protein adsorbed amounts on CS and HG1 are in the sensitivity limit of the measurement method since the quantities are lower than $5 \mathrm{mg} / \mathrm{g}$. Consequently, the adsorbed amount at $20^{\circ} \mathrm{C}$ can be almost considered as negligible for both nanogels (CS \& HG1) irrespective of $\mathrm{pH}$ in the investigated range.

\subsubsection{Protein Complexation}

As well-known, Immobilized Metal Affinity Chromatography (IMAC)-like approaches using Nickel-Nitriloacetic Acid (Nickel-NTA) and nickel ions as the active site for specific histidine immobilization has been largely reported. The $\mathrm{Ni}^{2+}$ ion has six coordination links with four requested for nickel ion immobilization on the support (i.e., NTA compound) and two remain links for nitrogen atoms of the side chain cycle of two histidine residues immobilization. This motivated the use of Ni for protein complexation in this study.

\section{Effect of $\mathrm{pH}$}

As already reported, the protein adsorption below the volume phase transition temperature of poly(N-alkylacrylamide) derivative nanohydrogel revealed low and in some cases no adsorption irrespective of $\mathrm{pH}$ and salinity. Then, the complexation study was investigated as a function of $\mathrm{pH}$, in 10-mM phosphate buffer and at $20^{\circ} \mathrm{C}$ (i.e., below the volume phase transition temperature of all prepared nanohydrogels). The obtained results are reported in Figure 6. The presence of Ni ions enhanced the protein immobilization principally at basic $\mathrm{pH}$ for CS and HG1. In fact, at basic $\mathrm{pH}$, the adsorption was found to be negative, whereas, the complexation was found to be highly marked. Surprisingly, for HG2, it is not possible to discriminate between adsorption and complexation since the same fixation amounts are observed during adsorption as discussed above. This unexpected result can be attributed to the chemical structure of the nanohydrogel. It is interesting to notice that the protein immobilized amounts on CS and HG1 at acidic pH are low and in the detection limit of proteins in the supernatant. Consequently, the protein complexation via imidazole groups in the presence of $\mathrm{Ni}$ ions can be considered effective on CS and HG1 compared to HG2 and special attention will be more dedicated to CS and HG1.

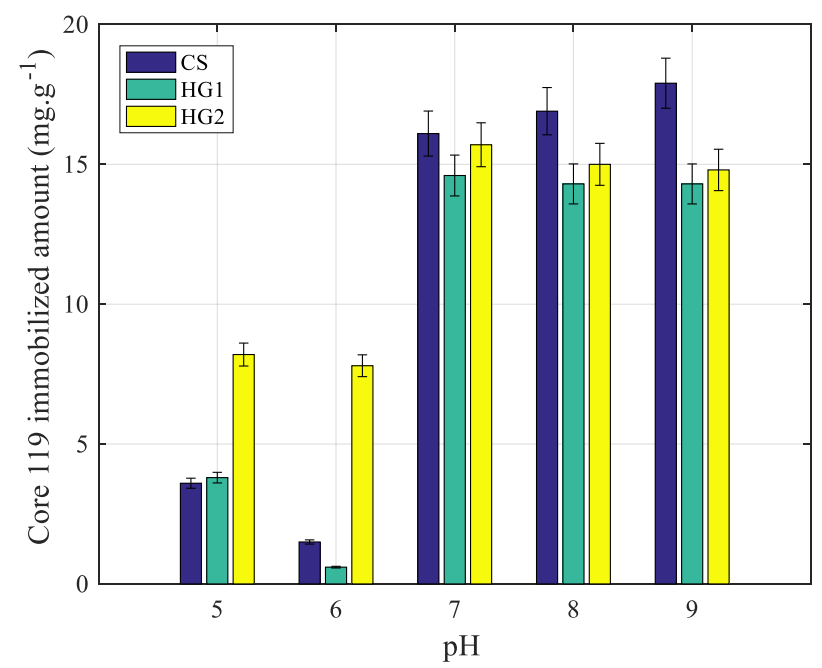

Figure 6. $\mathrm{pH}$ dependence of Core 119 fixation onto CS, HG1, and HG2 in presence of nickel. Conditions: phosphate buffers at different $\mathrm{pH}$ (from 5 to 9), ionic strength $10 \mathrm{mM}$, adsorption temperature $20^{\circ} \mathrm{C}$, $[\mathrm{Ni}]=10^{-2} \mathrm{M}$.

Effect of Nickel Concentration on Proteins Immobilization

The goal of this part is to investigate the influence of nickel concentration and $\mathrm{pH}$ on the complexation of a recombinant protein. Nickel concentration was then varied from $10^{-4} \mathrm{M}$ 
to $10^{-1} \mathrm{M}$ following the same methodology as described above. The obtained results are reported in Figure 7.
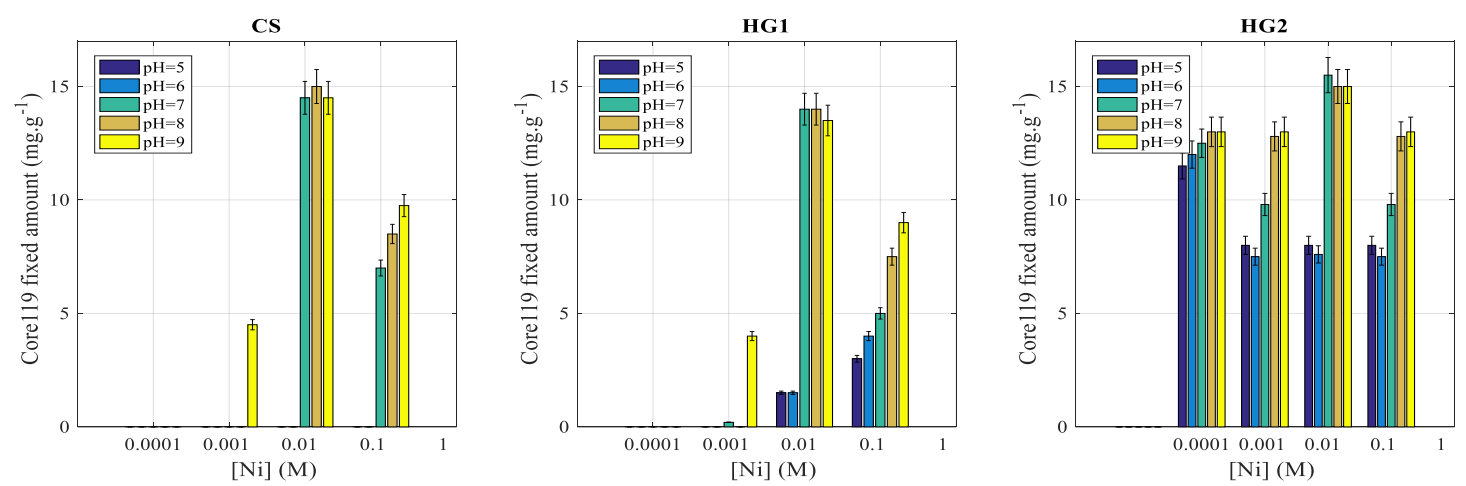

Figure 7. Effect of nickel concentration onto Core 119 fixation for core-shell (CS) particles, nanohydrogels HG1 and HG2. Conditions: phosphate buffers at different $\mathrm{pH}$ (ranging from 5 to 9), at $20^{\circ} \mathrm{C}$ and for various [Ni] from $10^{-4} \mathrm{M}$ to $10^{-1} \mathrm{M}$.

For HG2, the immobilized amount is found to be constant irrespective of Ni concentration and $\mathrm{pH}$. The observed complexation on CS and HG1 can be attributed to nickel atoms coordination on oxygen and nitrogen atoms present on the interfacial polymer structure. Surprisingly, for both core-shell (CS) and nanohydrogel (HG1), the observed complexation amounts are almost the same above $\mathrm{pH}=7$. Whereas, below $\mathrm{pH}=7$, the immobilization was found to be more marked on HG1 compared to CS. The maximum complexation efficiency was found to be for 10-mM nickel ions concentration. It is interesting to notice that the colloidal stability was maintained irrespective of nickel ions concentration. This is due to steric stabilization of the prepared nanohydrogel dispersions.

\subsubsection{Effect of Protein Concentration}

The effect of protein concentration on the complexation of HG2 was discarded since the adsorption was more pronounced irrespective of $\mathrm{pH}$ and nickel ions concentration. Then, the aim of this part is the investigation of the effect of protein concentration on the complexation efficiency on core-shell (CS) particles and on HG1 nanohydrogel particles. The obtained results are reported in Figure 8 with a $10^{-2}$ M Nickel concentration.
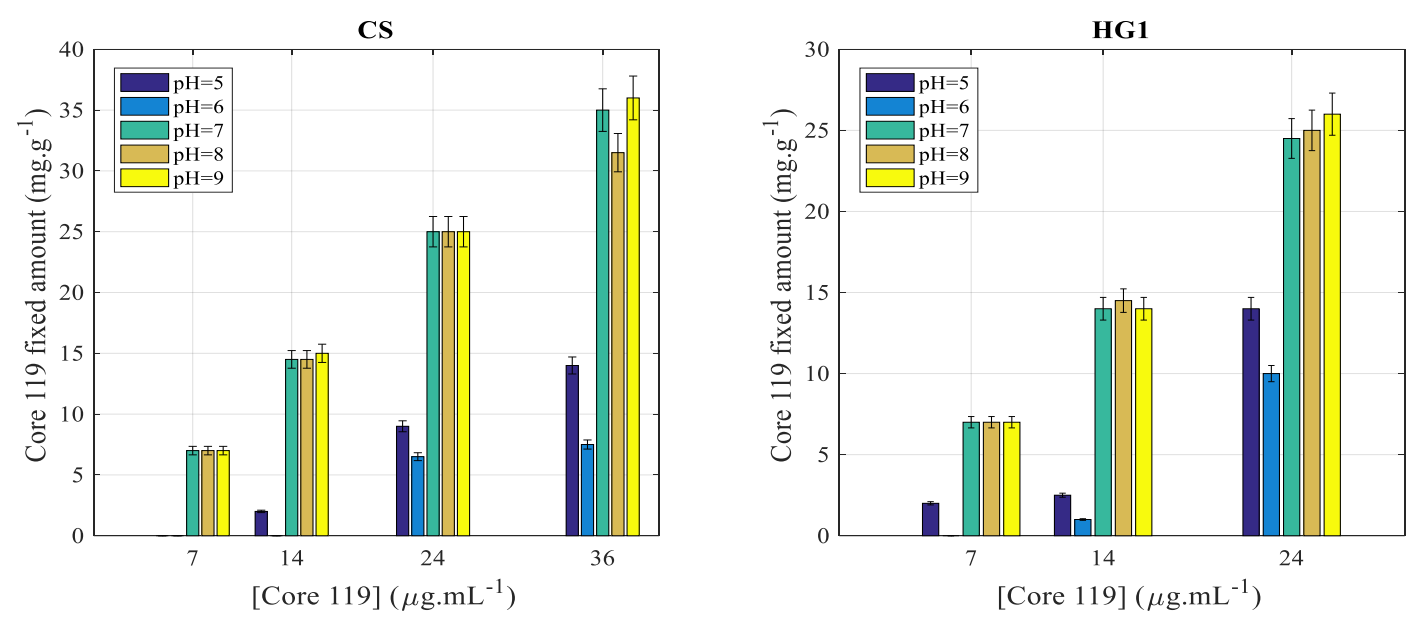

Figure 8. Effect of protein concentration on the complexation amount for CS and HG1 at pH ranging from 5 to 9 . The complexation was performed at $20^{\circ} \mathrm{C}$ and in the presence of $10-\mathrm{mM}$ nickel ions concentration 3.3. Protein extraction study. 
As it can be seen in Figure 8, the protein complexation amount increases with increasing the initial protein concentration. Similar tendency and almost the same complexation amounts are observed for both CS and HG1. For $\mathrm{pH} \leq 6$, the complexation efficiency is almost close to zero and even negligible, but increases slightly with increasing protein concentration. Whereas, above $\mathrm{pH}=6$, the complexation amount was found to be high and increases as a function of initial protein concentration.

Interestingly, for $\mathrm{pH} \geq 7$, the complexation amount increases almost linearly with increasing the initial protein concentration in the medium.

In this part, the release of complexed proteins on HG1 and CS particles was investigated by performing the complexation at $\mathrm{pH} \geq 7$ and the release at acidic $\mathrm{pH}$ at which the complexation was found to be less effective. In addition, the effect of imidazole on protein release was also investigated.

In order to estimate the real extracted amount, the adsorbed amount was subtracted, leading consequently to the purification yield (\% efficiency was deduced from proteins amount released with respect to initial proteins amount).

The protein complexation on $(1 \mathrm{mg} / \mathrm{mL})$ polymer particles was first performed at a given $\mathrm{pH}(7,8$ and 9) in the presence of $10^{-2} \mathrm{M}$ nickel ions concentration (optimal concentration as above described), at $20^{\circ} \mathrm{C}$ and the release was performed after removing the supernatant and replaced by equivalent volume of $10-\mathrm{mM}$ phosphate buffer $(\mathrm{pH}=5$ or $\mathrm{pH}=6)$. The obtained results are reported in Figure 9 for both polymer particles.
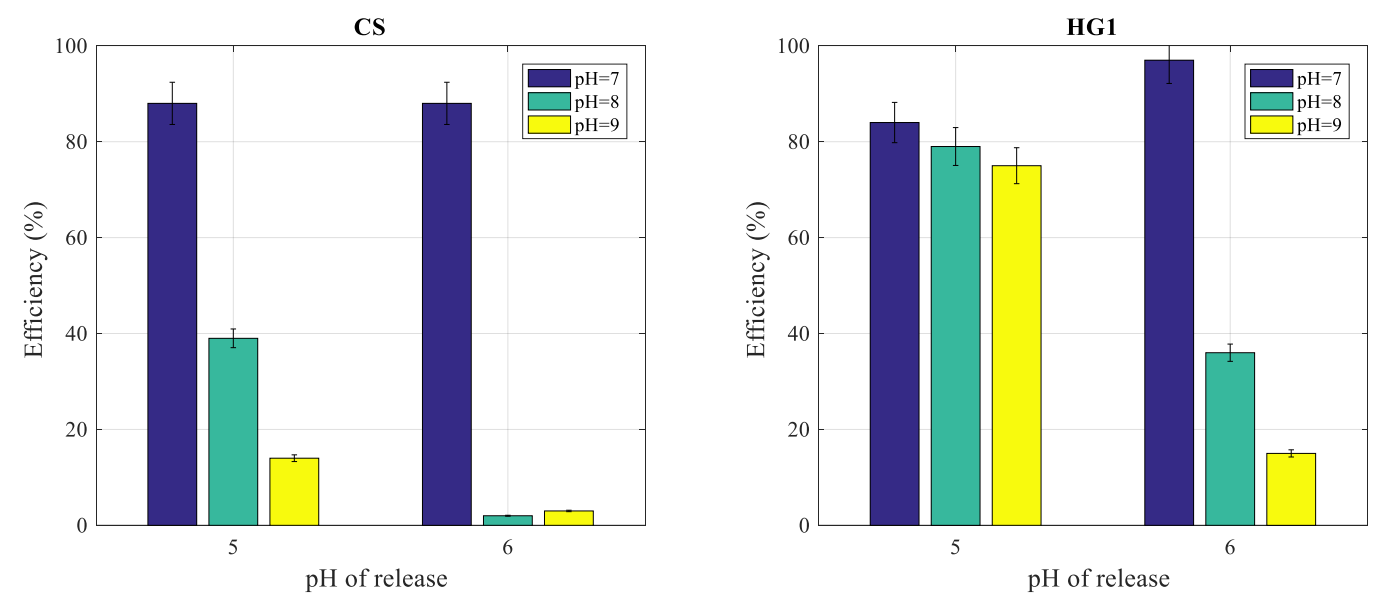

Figure 9. Effect of $\mathrm{pH}$ of fixing and that of salting out on protein release from CS (left) and HG1 (right) latexes. Conditions: phosphate buffers at different $\mathrm{pH}\left(5\right.$ and 6), temperature $20^{\circ} \mathrm{C},[\mathrm{Ni}]=10^{-2} \mathrm{M}$.

For CS (Figure 9, left), protein extraction after complexation at $\mathrm{pH}=7$ leads to $85 \%$ extraction efficiency at $\mathrm{pH}=5$ and $\mathrm{pH}=6$. Whereas, the complexation performed at $\mathrm{pH}=8$ or $\mathrm{pH}=9$ leads to low protein extraction yields at both releases $\mathrm{pH}$ (5 and 6).

For HG1 (Figure 9, right), the extraction yields are found to be around $80 \%$ when the release was performed at $\mathrm{pH}=5$ and irrespective of complexation $\mathrm{pH}$. As for $\mathrm{CS}$, the extraction at $\mathrm{pH}=6$ after complexation at $\mathrm{pH}=5$ leads to high extraction yield. Whereas, the release after complexation at $\mathrm{pH}=8$ and 9 leads to low extraction yield (below $40 \%$ ).

\section{Conclusions}

Nanohydrogel polymer particles were prepared via radical polymerization using charged initiator. The particles are spherical in shape and narrowly size distributed with a hydrodynamic mean diameter between $100 \mathrm{~nm}$ and $500 \mathrm{~nm}$. The effect of temperature on hydrodynamic particle size was investigated, revealing the swelling and deswelling of the particles, and consequently, the hydrogel character of the prepared polymer particles. 
The adsorption of a recombinant protein on the three nanogel particles was investigated at $20^{\circ} \mathrm{C}$ (i.e., below the volume phase transition of each particle). The adsorption was found to be negligible for negatively charged polystyrene core/crosslinked polyNIPAM shell and also on classical polyN-isopropylmethacrylamide nanogel $(<5 \mathrm{mg} / \mathrm{g})$. Whereas, the adsorption of carboxylic containing polyN-isopropylmethacrylamide nanogel was not found to be more marked due to the possible hydrogen interactions. The complexation of recombinant proteins via nickel ions was performed on CS and HG1 and found to be $\mathrm{pH}$ dependent. Whereas on HG2, it was not possible to discriminate between adsorption and complexation. The feasibility of recombinant protein extraction was performed in CS and HG1 and high extraction yields ( $\geq 80 \%$ ) were obtained principally when the complexation was performed at basic $\mathrm{pH}$ and the release at $\mathrm{pH}=5$ or $\mathrm{pH}=6$.

As a perspective of this work, it will be possible to scale-up the process for nanogel preparation and complexation. The possible limiting use of protein extraction will be related to the centrifugation step for phases separation in the case of such polymer-based nanohydrogels. But if the physical chemistry properties of the nanohydrogels are transferred on magnetic bead, then complexation, the extraction, and the purification processes will be easy to perform by using a single permanent magnet.

Author Contributions: Data curation, G.L.; validation, A.E.; writing-review and editing, N.L., A.E.; supervision, A.E. All authors have read and agreed to the published version of the manuscript.

Funding: This research received no external funding.

Acknowledgments: This work was first started in the CNRS-BioMerieux laboratory with the great help of Jean Luc Berland by providing recombinant proteins, and then extended afterwards at the LAGEPP CNRS-University of Lyon-1 Laboratory.

Conflicts of Interest: The authors declare no conflict of interest.

\section{References}

1. Çamli, T.; Tuncel, M.; Şenel, S.; Tuncel, A. Functional, uniform, and macroporous latex particles: Preparation, electron microscopic characterization, and nonspecific protein adsorption properties. J. Appl. Polym. Sci. 2002, 84, 414-429. [CrossRef]

2. Yu, B.; Tian, C.; Cong, H.; Xu, T. Synthesis of monodisperse poly(styrene-co-divinylbenzene) microspheres with binary porous structures and application in high-performance liquid chromatography. J. Mater. Sci. 2016, 51, 5240-5251. [CrossRef]

3. Rahman, M.; Heng, L.Y.; Futra, D.; Ling, T.L. Ultrasensitive Biosensor for the Detection of Vibrio cholerae DNA with Polystyrene-co-acrylic Acid Composite Nanospheres. Nanoscale Res. Lett. 2017, 12, 474. [CrossRef]

4. Marmey, P.; Lebaz, N.; Eissa, M.; Delair, T.; Elaissari, A. Polystyrene Latex Particles Bearing Primary Amine Groups via Soap-free Emulsion Polymerization. Polym. Int. 2020. [CrossRef]

5. Ghosh, R. Protein separation using membrane chromatography: Opportunities and challenges. J. Chromatogr. A 2002, 952, 13-27. [CrossRef]

6. Taitt, C.R.; Shriver-Lake, L.C.; Anderson, G.P.; Ligler, F.S. Surface Modification and Biomolecule Immobilization on Polymer Spheres for Biosensing Applications. In Biomedical Nanotechnology: Methods and Protocols; Hurst, S.J., Ed.; Methods in Molecular Biology; Humana Press: Totowa, NJ, USA, 2011; pp. 77-94. ISBN 978-1-61779-052-2.

7. Pichot, C.; Taniguchi, T.; Delair, T.; Elaïssari, A. Functionalized Thermosensitive Latex Particles: Useful Tools for Diagnostics. J. Dispers. Sci. Technol. 2003, 24, 423-437. [CrossRef]

8. Joglekar, M.; Trewyn, B.G. Polymer-based stimuli-responsive nanosystems for biomedical applications. Biotechnol. J. 2013, 8, 931-945. [CrossRef]

9. Motornov, M.; Roiter, Y.; Tokarev, I.; Minko, S. Stimuli-responsive nanoparticles, nanogels and capsules for integrated multifunctional intelligent systems. Prog. Polym. Sci. 2010, 35, 174-211. [CrossRef]

10. Zhao, Y.; Shi, C.; Yang, X.; Shen, B.; Sun, Y.; Chen, Y.; Xu, X.; Sun, H.; Yu, K.; Yang, B.; et al. pH- and Temperature-Sensitive Hydrogel Nanoparticles with Dual Photoluminescence for Bioprobes. ACS Nano 2016, 10, 5856-5863. [CrossRef] 
11. Sester, C.; Ofridam, F.; Lebaz, N.; Gagnière, E.; Mangin, D.; Elaissari, A. pH-Sensitive methacrylic acid-methyl methacrylate copolymer Eudragit L100 and dimethylaminoethyl methacrylate, butyl methacrylate, and methyl methacrylate tri-copolymer Eudragit E100. Polym. Adv. Technol. 2020, 31, 440-450. [CrossRef]

12. Teratanatorn, P.; Hoskins, R.; Swift, T.; Douglas, C.W.I.; Shepherd, J.; Rimmer, S. Binding of Bacteria to Poly(N-isopropylacrylamide) Modified with Vancomycin: Comparison of Behavior of Linear and Highly Branched Polymers. Biomacromolecules 2017, 18, 2887-2899. [CrossRef]

13. Rossi, S.; Lorenzo-Ferreira, C.; Battistoni, J.; Elaïssari, A.; Pichot, C.; Delair, T. Polymer mediated peptide immobilization onto amino-containing $\mathrm{N}$-isopropylacrylamide-styrene core-shell particles. Colloid Polym. Sci. 2004, 282, 215-222. [CrossRef]

14. Elaissari, A.; Delair, T.; Pichot, C. Thermally sensitive, hydrophilic, and reactive latex particles as versatile supports for biomolecules immobilization. In Progress in Colloid and Polymer Science; Tauer, K., Ed.; Springer: Berlin, Heidelberg, Germany, 2004; pp. 82-87.

15. Taylor, L.D.; Cerankowski, L.D. Preparation of films exhibiting a balanced temperature dependence to permeation by aqueous solutions—a study of lower consolute behavior. J. Polym. Sci. Polym. Chem. Ed. 1975, 13, 2551-2570. [CrossRef]

16. Shamim, N.; Hong, L.; Hidajat, K.; Uddin, M.S. Thermosensitive polymer (N-isopropylacrylamide) coated nanomagnetic particles: Preparation and characterization. Colloids Surf. B Biointerfaces 2007, 55, 51-58. [CrossRef] [PubMed]

17. Pelton, R.H.; Chibante, P. Preparation of aqueous latices with N-isopropylacrylamide. Colloids Surf. 1986, 20, 247-256. [CrossRef]

18. Kratz, K.; Hellweg, T.; Eimer, W. Influence of charge density on the swelling of colloidal poly(N-isopropylacrylamide-co-acrylic acid) microgels. Colloids Surf. Physicochem. Eng. Asp. 2000, 170, 137-149. [CrossRef]

19. Xing, Z.; Wang, C.; Yan, J.; Zhang, L.; Li, L.; Zha, L. pH/temperature dual stimuli-responsive microcapsules with interpenetrating polymer network structure. Colloid Polym. Sci. 2010, 288, 1723-1729. [CrossRef]

20. Nigro, V.; Angelini, R.; Rosi, B.; Bertoldo, M.; Buratti, E.; Casciardi, S.; Sennato, S.; Ruzicka, B. Study of network composition in interpenetrating polymer networks of poly( $\mathrm{N}$ isopropylacrylamide) microgels: The role of poly(acrylic acid). J. Colloid Interface Sci. 2019, 545, 210-219. [CrossRef]

21. Duracher, D.; Sauzedde, F.; Elaissari, A.; Perrin, A.; Pichot, C. Cationic amino-containing N-isopropylacrylamide-styrene copolymer latex particles: 1-Particle size and morphology vs. polymerization process. Colloid Polym. Sci. 1998, 276, 219-231. [CrossRef]

22. Duracher, D.; Sauzedde, F.; Elaïssari, A.; Pichot, C.; Nabzar, L. Cationic amino-containing N-isopropylacrylamide-styrene copolymer particles: 2-surface and colloidal characteristics. Colloid Polym. Sci. 1998, 276, 920-929. [CrossRef]

23. Li, Y.; Huang, G.; Zhang, X.; Li, B.; Chen, Y.; Lu, T.; Lu, T.J.; Xu, F. Magnetic Hydrogels and Their Potential Biomedical Applications. Adv. Funct. Mater. 2013, 23, 660-672. [CrossRef]

24. Karg, M.; Pastoriza-Santos, I.; Liz-Marzán, L.M.; Hellweg, T. A Versatile Approach for the Preparation of Thermosensitive PNIPAM Core-Shell Microgels with Nanoparticle Cores. ChemPhysChem 2006, 7, 2298-2301. [CrossRef]

25. Karg, M.; Wellert, S.; Prevost, S.; Schweins, R.; Dewhurst, C.; Liz-Marzán, L.M.; Hellweg, T. Well defined hybrid PNIPAM core-shell microgels: Size variation of the silica nanoparticle core. Colloid Polym. Sci. 2011, 289, 699-709. [CrossRef]

26. Nun, N.; Hinrichs, S.; Schroer, M.A.; Sheyfer, D.; Grübel, G.; Fischer, B. Tuning the Size of Thermoresponsive Poly(N-Isopropyl Acrylamide) Grafted Silica Microgels. Gels 2017, 3, 34. [CrossRef]

27. Carneiro, N.M.; Percebom, A.M.; Loh, W. Quest for Thermoresponsive Block Copolymer Nanoparticles with Liquid-Crystalline Surfactant Cores. ACS Omega 2017, 2, 5518-5528. [CrossRef] [PubMed]

28. Ferreira, G.A.; Loh, W. Liquid crystalline nanoparticles formed by oppositely charged surfactant-polyelectrolyte complexes. Curr. Opin. Colloid Interface Sci. 2017, 32, 11-22. [CrossRef]

29. Berndt, I.; Richtering, W. Doubly Temperature Sensitive Core-Shell Microgels. Macromolecules 2003, 36, 8780-8785. [CrossRef]

30. Wang, L.; Asher, S.A. Fabrication of Silica Shell Photonic Crystals through Flexible Core Templates. Chem. Mater. 2009, 21, 4608-4613. [CrossRef] [PubMed] 
31. Fujimoto, K.; Mizuhara, Y.; Tamura, N.; Kawaguchi, H. Interactions between Thermosensitive Hydrogel Microspheres and Proteins. J. Intell. Mater. Syst. Struct. 1993, 4, 184-189. [CrossRef]

32. Silva, C.S.O.; Lansalot, M.; Garcia, J.Q.; Taipa, M.Â.; Martinho, J.M.G. Synthesis and characterization of biomimetic nanogels for immunorecognition. Colloids Surf. B Biointerfaces 2013, 112, 264-271. [CrossRef]

33. Shiroya, T.; Tamura, N.; Yasui, M.; Fujimoto, K.; Kawaguchi, H. Enzyme immobilization on thermosensitive hydrogel microspheres. Colloids Surf. B Biointerfaces 1995, 4, 267-274. [CrossRef]

34. Yasui, M.; Shiroya, T.; Fujimoto, K.; Kawaguchi, H. Activity of enzymes immobilized on microspheres with thermosensitive hairs. Colloids Surf. B Biointerfaces 1997, 8, 311-319. [CrossRef]

35. Elaissari, A.; Holt, L.; Meunier, F.; Voisset, C.; Pichot, C.; Mandrand, B.; Mabilat, C. Hydrophilic and cationic latex particles for the specific extraction of nucleic acids. J. Biomater. Sci. Polym. Ed. 1999, 10, 403-420. [CrossRef]

36. Yi, P.; Wang, Y.; Zhang, S.; Zhan, Y.; Zhang, Y.; Sun, Z.; Li, Y.; He, P. Stimulative nanogels with enhanced thermosensitivity for therapeutic delivery via $\beta$-cyclodextrin-induced formation of inclusion complexes. Carbohydr. Polym. 2017, 166, 219-227. [CrossRef]

37. Zhou, Z.; Li, G.; Wang, N.; Guo, F.; Guo, L.; Liu, X. Synthesis of temperature/pH dual-sensitive supramolecular micelles from $\beta$-cyclodextrin-poly( $\mathrm{N}$-isopropylacrylamide) star polymer for drug delivery. Colloids Surf. B Biointerfaces 2018, 172, 136-142. [CrossRef] [PubMed]

38. Guo, F.; Li, G.; Ma, S.; Zhou, H.; Yu, X. Dual-responsive nanocarriers from star shaped poly(N-isopropylacrylamide) coated mesoporous silica for drug delivery. Int. J. Polym. Mater. Polym. Biomater. 2019, 0, 1-9. [CrossRef]

39. Qasim, M.; Udomluck, N.; Chang, J.; Park, H.; Kim, K. Antimicrobial activity of silver nanoparticles encapsulated in poly-N-isopropylacrylamide-based polymeric nanoparticles. Int. J. Nanomedicine 2018, 13, 235-249. [CrossRef]

40. Kim, Y.-H.; Babu, V.R.; Thangadurai, D.T.; Krishna Rao, K.S.V.; Cha, H.-R.; Kim, C.-D.; Joo, W.-H.; Lee, Y.-I. Synthesis, Characterization, and Antibacterial Applications of Novel Copolymeric Silver Nanocomposite Hydrogels. Bull. Korean Chem. Soc. 2011, 32, 553-558. [CrossRef]

41. Morris, L.R.; Mock, R.A.; Marshall, C.A.; Howe, J.H. Synthesis of Some Amino Acid Derivatives of Styrene1. J. Am. Chem. Soc. 1959, 81, 377-382. [CrossRef]

42. Bradford, M.M. A rapid and sensitive method for the quantitation of microgram quantities of protein utilizing the principle of protein-dye binding. Anal. Biochem. 1976, 72, 248-254. [CrossRef]

43. Hazot, P.; Delair, T.; Pichot, C.; Chapel, J.-P.; Elaissari, A. Poly(N-ethylmethacrylamide) thermally-sensitive microgel latexes: Effect of the nature of the crosslinker on the polymerization kinetics and physicochemical properties. Comptes Rendus Chim. 2003, 6, 1417-1424. [CrossRef]

44. Kawaguchi, H.; Fujimoto, K.; Mizuhara, Y. Hydrogel microspheres III. Temperature-dependent adsorption of proteins on poly-N-isopropylacrylamide hydrogel microspheres. Colloid Polym. Sci. 1992, 270, 53-57. [CrossRef]

45. Nabzar, L.; Duracher, D.; Elaïssari, A.; Chauveteau, G.; Pichot, C. Electrokinetic Properties and Colloidal Stability of Cationic Amino-Containing N-Isopropylacrylamide-Styrene Copolymer Particles Bearing Different Shell Structures. Langmuir 1998, 14, 5062-5069. [CrossRef]

46. Duracher, D.; Elaïssari, A.; Mallet, F.; Pichot, C. Adsorption of Modified HIV-1 Capsid p24 Protein onto Thermosensitive and Cationic Core-Shell Poly(styrene)-Poly(N-isopropylacrylamide) Particles. Langmuir 2000, 16, 9002-9008. [CrossRef]

47. Taniguchi, T.; Duracher, D.; Delair, T.; Elaïssari, A.; Pichot, C. Adsorption/desorption behavior and covalent grafting of an antibody onto cationic amino-functionalized poly(styrene-N-isopropylacrylamide) core-shell latex particles. Colloids Surf. B Biointerfaces 2003. [CrossRef]

(C) 2020 by the authors. Licensee MDPI, Basel, Switzerland. This article is an open access article distributed under the terms and conditions of the Creative Commons Attribution (CC BY) license (http://creativecommons.org/licenses/by/4.0/). 